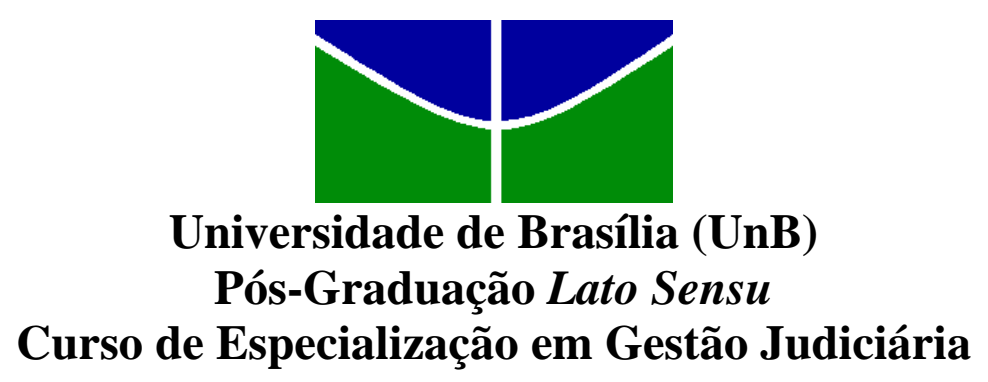

TEREZA CRISTINA JUREMA GARRIDO SATISFAÇÃO NO TRABALHO: UM ESTUDO NO
SUPERIOR TRIBUNAL DE JUSTIÇA 


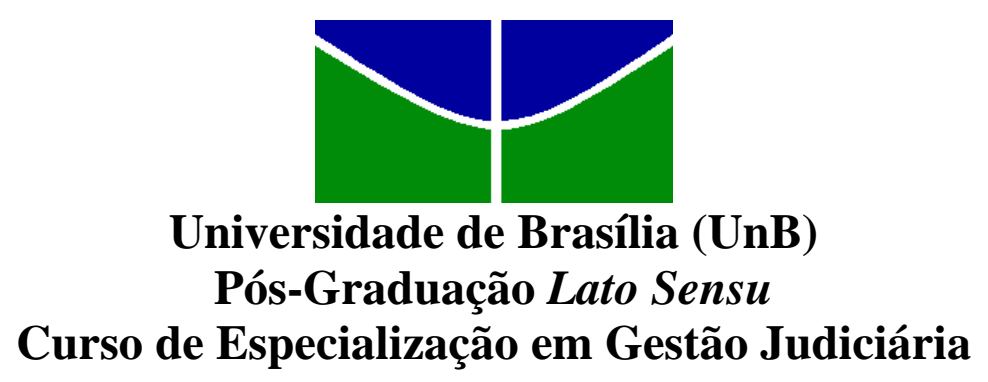

TEREZA CRISTINA JUREMA GARRIDO

\section{SATISFAÇÃO NO TRABALHO: UM ESTUDO NO SUPERIOR TRIBUNAL DE JUSTIÇA}

Monografia apresentada à Faculdade de Economia, Administração, Contabilidade e Ciência da Informação e Documentação (FACE) da Universidade de Brasília - UNB, como requisito parcial à obtenção do grau de Especialista em Gestão Judiciária.

Orientador: Prof. Drnd. Antonio Isidro Filho 
Garrido, Tereza Cristina Jurema.

Satisfação no trabalho: um estudo no superior tribunal de justiça / Tereza Cristina Jurema Garrido. - Brasília:

Universidade de Brasília, 2009.

1.Título. I. Satisfação no trabalho. II. Qualidade de vida 


\section{Resumo}

O presente trabalho teve por objetivo identificar o grau de satisfação na percepção dos servidores do Superior Tribunal de Justiça. O referencial teórico discute os conceitos e teorias relacionados a Satisfação no Trabalho. A pesquisa contou com a participação de 71 servidores distribuídos nas grandes áreas do tribunal. O instrumento utilizado foi a Escala de Satisfação de Trabalho, composta de 25 itens constituída por cinco sub-escalas que levaram os servidores a indicar o grau de satisfação com os colegas de trabalho, com o salário, a chefia, a natureza do trabalho e as promoções. Em relação aos resultados obtidos, o maior grau de satisfação foi em relação a chefia e o menor grau foi em relação as promoções.

Palavras-chave: Satisfação no trabalho, Qualidade de vida no trabalho, Desempenho. 


\begin{abstract}
This study aimed to identify the degree of satisfaction in the perception of the servers of the Superior Court of Justice. The theoretical framework discusses the concepts and theories related to satisfaction at work. The research involves the participation of 71 servers distributed in large areas of the court. The instrument was the Job Satisfaction Scale, consisting of 25 items consisting of five sub-scales which led the server to indicate the degree of satisfaction with co-workers with the wages, the managers, the nature of work and promotions. For the results, the highest level of satisfaction was on leadership and less was on the promotions
\end{abstract}

Keywords: Satisfaction at work, Quality of life at work, Performance. 


\section{Sumário}

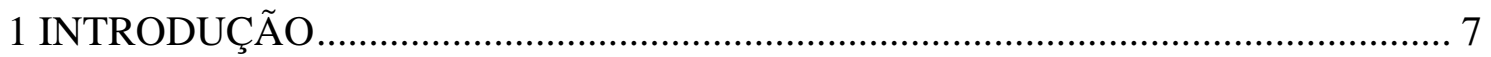

1.1 O problema e sua importância ......................................................................... 9

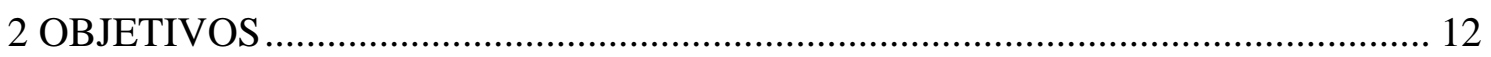

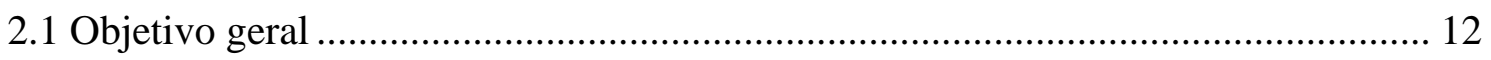

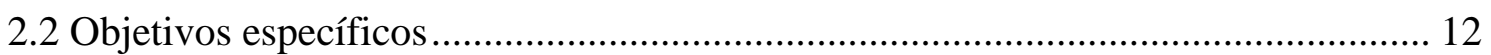

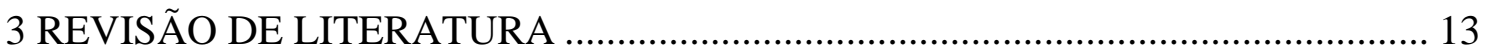

3.1 A evolução das relações de trabalho....................................................................... 13

3.2 Primeiros estudos sobre a Satisfação do Indivíduo no Trabalho................................. 14

3.3 A evolução do conceito de QVT (Qualidade de Vida no Trabalho) ......................... 19

3.4 Teoria das Características do Trabalho de Hackman e Oldham.................................. 21

3.5. A Satisfação no Trabalho ............................................................................... 21

3.6 Medidas para investigação da Satisfação no Trabalho............................................... 24

4 CARACTERÍSTICAS DA ORGANIZAÇÃO ESTUDADA ……………………….... 26

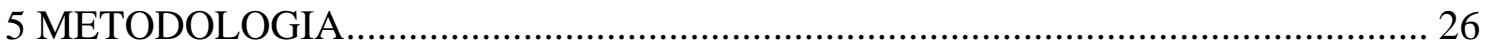

5.1 Tipo de pesquisa …………………………………….............................. 26

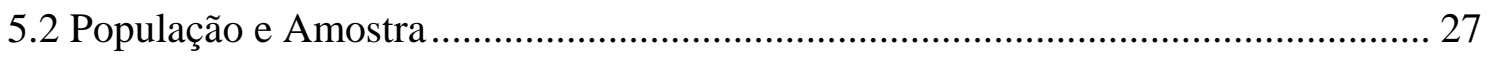

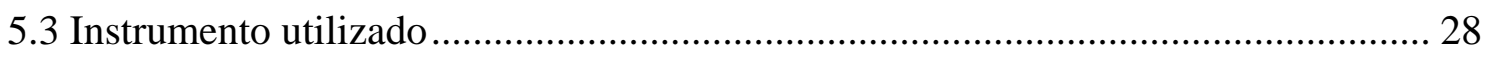

5.4 Procedimentos de coleta e análise dos dados ....................................................... 29

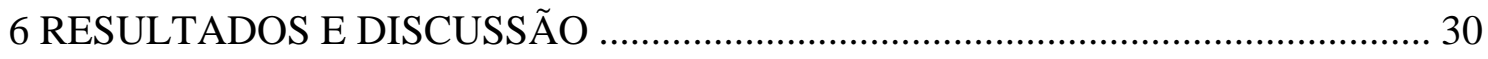

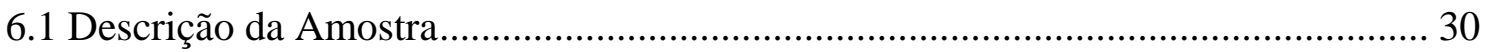

6.2 Descrição da Escala de Satisfação no Trabalho …………………………………..... 32

6.3 Descrição das Dimensões da Satisfação com o Trabalho............................................. 34

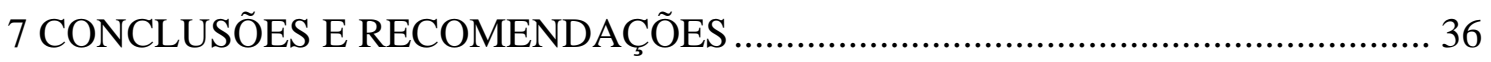

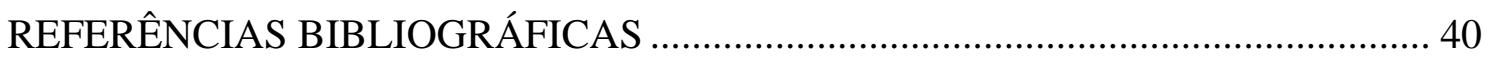

ANEXO A - Questionário “Satisfação no Trabalho”......................................................... 42 


\section{INTRODUÇÃO}

O século 21 é marcado por amplas transformações no ambiente empresarial, onde a competição é uma marca expressiva. As mudanças na economia mundial, na tecnologia, na organização produtiva e sobretudo nas relações de trabalho, trazem a tona o binômio Indivíduo x Trabalho. Em um primeiro momento, no início do século, o objetivo maior era a elevação da produtividade e maiores ganhos de capital. A seguir a preocupação passou a ser o comportamento do indivíduo e sua satisfação com o contexto. Portanto, tivemos na primeira metade deste século, dois momentos bem distintos: a concepção voltada para a produtividade e a preocupação com a satisfação do trabalhador.

A partir do início da segunda metade do século, surgem as primeiras teorias que associam esses dois elementos. Basicamente, pensava-se que não só era possível unir a produtividade à satisfação, como o bom desempenho do trabalhador the proporcionava satisfação e realização. (MCGREGOR, 1980 apud RODRIGUES, 2008). É a era do conhecimento, com a construção do mundo sem fronteiras e com a globalização da economia, embora ainda em fase de construção e consolidação, percebe-se uma forte tendência para que a padronização imposta pela revolução industrial seja reformada.

Nos anos 1960, os movimentos reivindicatórios dos trabalhadores norteamericanos e a não passividade dos estudantes franceses tiveram reflexos no interior das organizações e os conflitos e crises foram instaurados. Inicia-se então a recuperação do valor do convívio. A conseqüência foi um indivíduo mais consciente, o que favoreceu o início dos estudos sobre Qualidade de Vida no Trabalho (QVT), no interior dos Estados Unidos e Inglaterra.

A década de 1970, especialmente incentivada pelo sucesso industrial japonês, traduzida pelo Toyotismo, quando os japoneses descobriram que os modelos Fordista e Taylorista não satisfaziam os seu anseios, é marcada pelos primeiros movimentos e aplicações estruturadas e sistematizadas no interior da organização, utilizando a Qualidade de Vida no Trabalho (QVT). Nos anos 1980, o crescente avanço tecnológico, as mudanças políticas, econômicas e sociais como um todo, suscitam a modernização das organizações e tornam o contexto dinâmico e instável. Diante de toda essa diversidade de situações, surge a necessidade de alguém com responsabilidade e 
autoridade para gerir, decidir, planejar, coordenar, controlar, enfim administrar todos os aspectos de uma organização, ou seja, a necessidade de um gerente.

Várias teorias passaram a discutir o gerente. A importância deste profissional na organização é vista por vários autores pela sua influência no condicionamento comportamental e eficácia organizacional (MACCOBY, 1977; DRUCKER, 1978; REDDIN, 1986 apud RODRIGUES, 2008). E este gerente parece ser o indivíduo mais vulnerável aos problemas e conflitos quando temos de um lado o capital e do outro, os trabalhadores. Segundo Rodrigues (2008), as peculiaridades da função executiva desse gerente serão determinantes do nível da QVT.

Uma recente pesquisa do Gallup, segundo Robbins (2002), entrevistou norteamericanos de todos os cantos dos Estados Unidos para descobrir quais suas atitudes em relação ao ambiente de trabalho. Em uma escala de 1 a 5 , com 5 representando “extremamente satisfeito”, 72\% responderam com nota 4 ou 5 sobre satisfação com o emprego. Uma análise mais detalhada indicou que boa parte dessa satisfação devia-se ao fato de que os empregos atendiam, de maneira geral, às necessidades básicas dos trabalhadores. Estes consideravam os seguintes fatores como críticos para sua satisfação e bom desempenho: a oportunidade de fazer o que melhor sabiam; ter suas opiniões levadas em consideração e ter a oportunidade de aprender e crescer. $82 \%$ dos respondentes declararam ter a oportunidade de fazer todos os dias o que melhor sabiam e $84 \%$ disseram que tinham a oportunidade de aprender e crescer no trabalho.

De acordo com Robbins (2002),

O trabalho de uma pessoa é muito mais do que as atividades óbvias, como organizar papéis, atender clientes ou dirigir um caminhão. $\mathrm{O}$ trabalho requer a convivência com colegas e superiores, a obediência a regras e políticas organizacionais, o alcance de padrões de desempenho e a aceitação de condições de trabalho geralmente abaixo do ideal, entre outras coisas. Um interesse dos gerentes quanto à satisfação com o trabalho costuma centrar-se em seus efeitos sobre o desempenho dos funcionários.

Segundo Siqueira (2008), estudiosos como Herzberg, Mausner e Snyderman (1959), Vroom (1964) e Hackman e Porter (1971) defendiam a noção de ser:

A satisfação no trabalho um componente da motivação que levava trabalhadores a apresentarem indicadores de comportamentos de trabalho importantes para os interesses empresariais, tais como aumento do desempenho e da produtividade, permanência na empresa e redução de faltas ao trabalho. 
Satisfação no trabalho passa a ser compreendida nos dias atuais, como "um resultado do ambiente organizacional sobre a saúde do trabalhador e é apontada como um dos três componentes psicossociais do conceito de bem-estar no trabalho". (SIQUEIRA, 2008)

De acordo com Spector (2008) uma das principais tarefas realizadas pelos psicólogos organizacionais é avaliar a satisfação dos funcionário no trabalho, e dessa forma, auxiliar as empresas a tomarem medidas para melhorá-la. Os estudos nessa área têm sido exaustivos no que tange as causas e conseqüências da satisfação no trabalho. Ainda segundo o autor, a satisfação no trabalho tem sido apresentada como a causa de importantes realizações das organizações e dos funcionários, do desempenho no trabalho à saúde e longevidade.

Como medimos a satisfação com o trabalho? Qual a sua importância sobre a produtividade, o absenteísmo e a rotatividade dos funcionários?

Sendo assim, a presente monografia buscará responder à seguinte questão de pesquisa: Qual o grau de satisfação com o trabalho dentre os servidores do Superior Tribunal de Justiça (STJ)?

\subsection{O problema e sua importância}

O trabalho ocupa um grande espaço na vida das pessoas. A maior parte das pessoas exerce uma atividade laboral e grande parte de suas vidas é passada dentro das organizações. A relação do homem com o trabalho é de fundamental importância e é por meio dela que o homem consegue o seu sustento e o suprimento de necessidades mais elevadas, como realização, crescimento e desenvolvimento de habilidades, entre outras.

Mas se por um lado o trabalho apresenta-se como enobrecedor e capaz de elevar o status propiciando ao trabalhador uma identidade, por outro lado o trabalho é muitas vezes percebido como indesejado, como se configura na sociedade atual, mostrando-se como fragmentado e sem sentido, burocratizado e rotineiro, cheio de exigências ou incompatível com a vida social e familiar (RODRIGUES, 2008).

Estresse, cansaço, fadiga e mau humor. Estes são sintomas comuns de quem cumpre longas jornadas de trabalho, fica muito tempo sem tirar férias ou de quem não 
tem uma folga sequer para quebrar a rotina. Além disso, esses problemas também afetam pessoas que passam oito horas diárias trabalhando e só têm o horário de almoço para se distrair. Por esta razão, a maneira como o funcionário lida com o trabalho deve mudar e, sobretudo, o modo como as empresas lidam com seus colaboradores. Portanto, a qualidade de vida deve ser uma constante em todos os lugares, inclusive no ambiente trabalho. A idéia é buscar o bem-estar, principalmente durante o tempo em que se está na empresa.

O conceito de bem-estar é extremamente relativo, uma vez que depende da percepção de cada ser humano sobre si e sobre o ambiente que o cerca. Bem-Estar no trabalho é a satisfação no trabalho, o envolvimento com o trabalho, o comprometimento organizacional.

Saber o que motiva, o que satisfaz o trabalhador é descobrir o procedimento adotado com relação a ele, para que ele melhore o seu bem-estar no trabalho e, consequentemente, o seu desempenho profissional.

Segundo Tamayo, et al (2008):

Especialistas consideram que aferir níveis de satisfação dos trabalhadores poderia ser uma estratégia para monitorar o quanto as empresas conseguem, ou não, promover e proteger a saúde e o bemestar daqueles que com elas colaboram como força de trabalho.

A partir dos anos 1990 o interesse dos pesquisadores passou a ser acerca de outros conceitos afetivos, tais como afetos positivos e negativos, estado de ânimo e emoções conseqüentes de experiências emocionais no contexto do trabalho e que se tornaram importantes para a compreensão de fenômenos como estresse, burnout, sofrimento e saúde mental dos trabalhadores. (BRIEF; WEISS (2002); GODIM; SIQUEIRA, 2004 apud TAMAYO, et al, 2008).

As conseqüências da satisfação no trabalho têm sido apontadas como de suma importância, seja para as organizações, em termos de suas potenciais implicações sobre a eficiência, produtividade, qualidade das relações de trabalho, níveis de absenteísmo / turnover e comprometimento organizacional, seja em termos de seus possíveis impactos sobre a saúde e bem-estar dos trabalhadores.

Segundo Spector (2005), "alguns estudos correlacionais demonstram que a satisfação no trabalho tem relação com variáveis da saúde”. Esses estudos descobriram que servidores insatisfeitos apresentam mais sintomas físicos, como insônia e dores de estômago, o que os funcionários satisfeitos e a correlação entre insatisfação e emoções 
no trabalho, como ansiedade e depressão. "Esses estados emocionais negativos podem ser considerados indicadores da condição do bem-estar no trabalho”.

A expressão “satisfação no trabalho” representa “a totalização do quanto o indivíduo que trabalha vivencia experiências prazerosas no contexto das organizações” (SIQUEIRA, 2008). De acordo com a autora, as dimensões que conseguiram se manter ao longo de anos de estudo, para explicar a satisfação no trabalho, foram: satisfação com o salário, com os colegas de trabalho, com a chefia, com as promoções e com o próprio trabalho. Cada uma dessas cinco dimensões compreende um foco, uma fonte ou origem de tais experiências prazerosas.

As análises dos índices de satisfação no trabalho passaram a ser constantes em diversas organizações. Os institutos de pesquisa quando elaboram o ranking das melhores empresas para se trabalhar incluem os índices de satisfação no trabalho como um dos principais indicadores das melhores empresas.

Outra questão importante refere-se à contribuição da satisfação no trabalho para a satisfação na vida de uma forma geral. Ela é considerada um indicador do nível de felicidade e bem-estar emocional. De acordo com Hugick e Leonard (1991) e Adams e King (1996) citados por Spector (2008), "segundo uma pesquisa Gallup, 87\% das pessoas estão satisfeitas com suas vidas”. Estudos sobre o nível de satisfação na vida descobriram que a mesma se correlaciona com a satisfação no trabalho.

"Para se constituir em uma medida útil de satisfação é indispensável que ela permita avaliar não um amplo leque de dimensões do trabalho, mas, sim, aqueles aspectos que a teoria aponta como dimensões do conceito de satisfação” (SIQUEIRA, 2008). Além disso, a medida deve ser de fácil aplicação e permitir a transformação dos dados em resultados que possam ser interpretados prontamente do ponto de vista da pesquisa científica e da prática gerencial.

No presente estudo, o grau de satisfação com o trabalho será medido a partir das respostas aos itens do questionário (Escala de Satisfação no Trabalho - EST), no qual serão abordadas cinco dimensões: satisfação com os colegas de trabalho, satisfação com o trabalho, satisfação com a chefia, satisfação com a natureza do trabalho e satisfação com as promoções. 


\section{OBJETIVOS}

\subsection{Objetivo geral}

Para a realização deste projeto de pesquisa tem-se por objetivo geral identificar e avaliar o grau de satisfação com o trabalho dentre os servidores do Superior Tribunal de Justiça (STJ). Pretende-se ainda, diante dos resultados obtidos, contribuir efetivamente para uma gestão de pessoal que promova a satisfação no trabalho e garanta ao Tribunal o alcance dos seus objetivos organizacionais.

\subsection{Objetivos específicos}

Analisar/Identificar as percepções dos servidores do STJ acerca das seguintes dimensões:

i.satisfação com os colegas de trabalho, que compreendem o contentamento com a colaboração, a amizade, a confiança e o relacionamento mantido com os colegas de trabalho

ii.satisfação com o salário, que compreende o contentamento com o que recebe como salário se comparado com o quanto o indivíduo trabalha, com sua capacidade profissional, com o custo de vida e com os esforços feitos na realização do trabalho;

iii.satisfação com a chefia, que compreende o contentamento com a organização e a capacidade profissional do chefe, com o seu interesse pelo trabalho dos subordinados e entendimento entre eles;

iv.satisfação com a natureza do trabalho, que compreende o contentamento com o interesse despertado pelas tarefas, com a capacidade destas em absorver o trabalhador e com a variedade das mesmas; e

v. satisfação com as promoções, que compreende o contentamento com o número de vezes que já recebeu promoções, com as garantias oferecidas a quem é promovido, com a maneira como a empresa realiza promoções e com o tempo de espera pela promoção. 


\section{REVISÃO DE LITERATURA}

\subsection{A evolução das relações de trabalho}

No início do século XVIII houve uma grande mudança nos processos industriais. A população mundial crescia aceleradamente, consequentemente o mercado consumidor estimulava a produção em grande escala e o aprimoramento tecnológico. A mão de obra crescia devido ao crescimento populacional e ao meio rural. A hegemonia tecnológica era da Inglaterra, uma vez que era detentora do mercado consumidor e do transporte.

As indústrias se modernizavam e sinalizavam a necessidade de uma mudança nos processos produtivos. O “acúmulo de capital” era a palavra de ordem entre os donos de fábricas e comerciantes (TREVELYAN, 1967; HOBSBAW, 1981 apud RODRIGUES, 2008).

O trabalhador vivia em condições desumanas, com jornadas de trabalho que chegavam a 18 horas diárias (MALTHUS, 1946 apud RODRIGUES, 2008). As necessidades básicas do trabalhador não eram consideradas.

Após a Guerra Civil, em 1868, os Estados Unidos e a Europa viveram grandes mudanças. Na Europa uma grande crise de desemprego motivou milhares de trabalhadores a emigrarem para os Estados Unidos (REMOND, 1961; CORIAT, 1980 MALTHUS, 1946 apud RODRIGUES, 2008).

Existia mercado, a expectativa para o consumo de produtos industrializados e mão de obra abundante e barata, porém não especializada. Mas havia um grande problema: os processos produtivos, uma vez que eram os artesãos as pessoas que detinham o conhecimento total do fazer. Além disso, esses artesãos bloqueavam a introdução de trabalhadores não especializados. Com isso a produtividade era baixa.

Taylor (1987) aplica seus princípios à divisão do trabalho em tarefas simples e previamente definidas e a utilização da mão-de-obra não especializada passou a ser possível e viável. Dessa forma, a indústria assumiu o controle do processo produtivo e pôde aumentar substancialmente sua produtividade e produção, utilizando-se da mãode-obra do trabalhador não especializado. A filosofia proposta era a racionalização da produção trazendo como produtos finais a produtividade e a motivação econômica do trabalhador. 
Para Taylor (1987, p. 32)

Prosperidade para o empregado significa, além de salários mais altos do que os recebidos habitualmente pelos obreiros de sua classe, o aproveitamento dos homens de modo mais eficiente, habituando-os a desempenhar os tipos de trabalhos mais elevados, para os quais tenham aptidões naturais e atribuindo-lhes, sempre que possível, esses gêneros de trabalhos.

Segundo Limongi-França (2008)

Trata-se de reconhecer que grande parte das relações de trabalho, de suas práticas e seus valores nasce de experiências no chão de fábrica, dos processos de controle da produção, dos tempos e movimentos, evoluindo para qualidade total e critérios de excelência.

Ainda segundo a autora, “a razão do saber em Taylor era de natureza tecnológica, por meio do uso de melhores técnicas e métodos pelos empregados, estes vistos como uma parte da complexa engrenagem produtiva”. De acordo com Souza (2004), durante muitos anos este modelo de gestão foi utilizado pelas organizações, onde o principal objetivo era o aumento da produtividade, não levando em consideração os aspectos relacionados à satisfação no trabalho. A ênfase foi colocada na eficiência, não importando a que custo humano e social. Os trabalhadores tornaram-se dependentes do emprego oferecido pelas fábricas. A cultura aceitava e encorajava a exploração.

Os teóricos clássicos deram pouca atenção aos aspectos humanos da organização. O fracasso do taylorismo foi inevitável. “As organizações começaram a sentir a necessidade de rever o modelo de Taylor, buscando a inovação e a melhoria contínua”. (SOUZA, 2004)

Em seguida, "surge um movimento que enfatiza as relações humanas e abre espaço para as questões relativas à saúde física e mental ou psicológica do trabalhador”. (LIMONGI-FRANÇA, 2008, p. 27)

\subsection{Primeiros estudos sobre a Satisfação do Indivíduo no Trabalho}

Em 300 a.c. Euclides de Alexandria, ao utilizar como instrumento os princípios de geometria, melhorou o método de trabalho dos agricultores as margens do Rio Nilo. Em 287 a.c. Arquimedes, ao utilizar como instrumento a “Lei das Alavancas”, reduziu o esforço físico dos trabalhadores, demonstram que a Qualidade de Vida no Trabalho é 
uma preocupação antiga do homem, com o objetivo de alcançar satisfação e bem-estar na realização do seu trabalho. (RODRIGUES, 2008)

Nos séculos VIII e XIX, com a sistematização de outros métodos de produção, aumentam as preocupações com as condições de vida no trabalho e a influência destas na produção.

As primeiras preocupações científicas sobre a influência das condições de trabalho na produtividade industrial surgiram no início dos anos 20, mas especificamente entre 1924 e 1927, na "Western Eletric Company”, uma empresa que sempre manteve um alto nível de salários e boas condições de trabalho. Apesar desses fatores positivos, segundo Motta (1985 apud RODRIGUES, 2008, p. 36), “o homem era encarado como uma unidade isolada, cuja eficiência poderia ser estimada cientificamente”. Quanto aos resultados das pesquisas Homans (1971 apud RODRIGUES, 1995, p. 36) diz que:

Os pesquisadores concluíram que o resultado negativo foi obtido não porque a relação não existisse, mas porque era impossível isolar essas de outras variáveis que entravam em qualquer determinação de eficiência produtiva [...] o resultado obtido comprovou a importância do fator psicológico.

A direção da Western Eletric ficou inquieta com os resultados e com o objetivo de determinar que fatores tinham influência decisiva no aumento da produção contratou o suporte científico do Departamento de Pesquisas Industriais da "Harvard Graduate School of Business Administration”, da qual fazia parte Elton Mayo. Segundo Mottez (1971 apud RODRIGUES, 2008, p. 37) “em abril de 1927 foi iniciado um novo experimento que tinha por objetivo o estudo dos efeitos da fadiga e da monotonia”. A pesquisa realizada por Mayo seria a seguinte:

A tarefa escolhida foi a montagem de relés telefônicos, sendo que cinco moças selecionadas montariam os relés e a sexta forneceria as peças necessárias às montadoras. $\mathrm{O}$ experimento foi dividido em duas partes: as pesquisas de Sala de Teste de Montagem de Relés e o Programa de entrevistas. Para a primeira parte do experimento, as seis moças foram separadas dos outros trabalhadores em uma sala especial. Nesta sala, havia um supervisor, que deveria realizar suas tarefas convencionadas e um observador que tinha por função observar todos os dados, tanto referentes à produção como também comentários ou posicionamentos das trabalhadoras, referentes ou não ao trabalho. (RODRIGUES, 2008, p. 37)

Algumas conclusões sobre a primeira parte da pesquisa realizada por Mayo foram: 
O trabalho é uma atividade grupal; a necessidade de reconhecimento e segurança e senso de pertencer a algo são mais importantes na determinação da moral do operário e da produtividade do que as condições físicas sob as quais ele trabalha; o trabalhador é uma pessoa cujas atitudes e eficiências são condicionadas pelas demandas sociais, tanto dentro como fora da fábrica. (RODRIGUES, 2008, p. 38)

A segunda parte da pesquisa - a entrevista - foi realizada com o intuito de fazer um levantamento das atitudes e pretensões dos trabalhadores. De 1923 a 1930, foram entrevistados 21.126 servidores. (TREWATH; NEWPOR, 1979 apud RODRIGUES, 2008, p. 39):

[...] os entrevistadores desenvolveram uma técnica chamada entrevista não dirigida. Com pouca direção dos entrevistadores, os empregados tinham permissão para falar livremente, sem temor de represálias para si, colegas ou supervisores De fato, alguns entrevistados disseram que se sentiam melhor porque podiam fala a alguém que os escutava. Outros atribuíram melhorias em suas condições de trabalho às entrevistas.

Em 1932, por motivos econômicos e psicológicos provocados pela recessão, os experimentos tiveram de ser paralisados, mas é incontestável a grande relevância das contribuições de Mayo para o estudo do comportamento humano e qualidade de vida no trabalho.

Abraham Maslow foi o "primeiro a relacionar as necessidades humanas num quadro teórico abrangente na sua teoria da motivação humana, baseada numa hierarquia das necessidades humanas básicas (LOPES, 1980 apud RODRIGUES, 2008, p. 40). A "hierarquia das necessidades" de Maslow é composta por cinco necessidades fundamentais, quais sejam: fisiológicas, segurança, amor, estima e auto-realização., segundo Maslow (apud ROBBINS, 2002), dentro de cada ser humano existe uma hierarquia de 5 necessidades, são elas:

1-Fisiológicas: incluem fome, sede, abrigo, sexo e outras necessidades corporais; 2-Segurança: inclui segurança e proteção contra danos físicos e emocionais; 3-Sociais: incluem afeição, aceitação, amizade e sensação de pertencer a um grupo; 4-Estima: inclui fatores internos de estima, como respeito próprio, realização e autonomia; e fatores externos de estima, como status, reconhecimento e atenção; 5-Autorealização: a intenção de tornar-se tudo aquilo que a pessoa é capaz de ser; inclui crescimento, auto-desenvolvimento e alcance do próprio potencial.

De acordo com McGregor (1980 apud RODRIGUES, 2008, p. 42), “o trabalho oferece poucas oportunidades de satisfação das necessidades egoístas, principalmente para as pessoas situadas nos níveis inferiores da hierarquia”. As necessidades egoístas 
são aquelas que englobam a auto-estima (auto-respeito e confiança, autonomia, realização, competência e conhecimento) e a própria reputação (“status”, reconhecimento e aprovação). As teorias $\mathrm{X}$ e $\mathrm{Y}$ agrupam as idéias relacionadas ao indivíduo-trabalho e são apresentadas da seguinte forma:

A Teoria $\mathrm{X}$ representa o controle existente sobre os recursos humanos da empresa. Segundo esta teoria o ser humano não gosta do trabalho e o evita; ele precisa ser forçado, controlado e dirigido; o ser humano prefere ser dirigido e tem pouca ambição; ele busca apenas a segurança.

A teoria Y evidencia o fato de que o desenvolvimento dos recursos humanos é muito mais otimizado e pode ser melhor aproveitado. Conforme esta teoria o dispêndio de esforço no trabalho é algo natural; o controle externo e a ameaça não são meios adequados de se obter trabalho; o ser humano exercerá autocontrole e auto-direção, se suas necessidades forem satisfeitas; o ser humano busca a responsabilidade; o empregado exercerá e usará sua engenhosidade, quando lhe permitirem auto-direção e autocontrole. Esta teoria constituiu-se um grande avanço para a qualidade de vida do indivíduo no trabalho.

Frederick Herzberg formulou sua teoria da motivação com base em um estudo empírico realizado com 200 engenheiros e contadores de 9 indústrias de metais em Pittsburg. Herzberg (1968, apud RODRIGUES, 2008) “acreditando que a relação de uma pessoa com seu trabalho é básica e que esta atitude pode muito bem determinar o seu sucesso ou fracasso", investigou a questão "O que as pessoas desejam de seu trabalho?”. Ele pediu às pessoas que descrevessem, em detalhes, situações nas quais se sentiram excepcionalmente bem ou mal a respeito de seu trabalho. As respostas foram então tabuladas e categorizadas. Das respostas categorizadas, Herzberg concluiu que: aquelas referentes aos momentos em que as pessoas se sentiram bem com o trabalho eram significativamente diferentes das referentes aos momentos em que elas se sentiram mal; algumas características tendem a estar consistentemente relacionadas com a satisfação com o trabalho e outras com a insatisfação; os fatores intrínsecos, como o trabalho em si, a responsabilidade e a realização, parecem estar relacionados com a satisfação com o trabalho (os respondentes que se sentiam bem com seu trabalho atribuíam estes fatores a si mesmos); e os respondentes que se sentiam insatisfeitos tendiam a indicar fatores extrínsecos, com a supervisão, a remuneração, as políticas da empresa e as condições de trabalho. 
De maneira resumida, os fatores que contribuem para a insatisfação com o trabalho são os fatores higiênicos. Aqueles fatores como políticas da empresa, administração, supervisão e remuneração que, quando adequados, tranqüilizam os trabalhadores; e os fatores que contribuem para a satisfação com o trabalho são os fatores motivadores, como realização, reconhecimento, responsabilidade, o próprio trabalho e progresso ou desenvolvimento. De acordo com Herzberg (1968 apud RODRIGUES, 2008, p. 45), “o oposto da satisfação com o trabalho não seria a insatisfação, mas, nenhuma satisfação com ele e igualmente o oposto da insatisfação seria nenhuma insatisfação com o trabalho”.

Quando os fatores de higiene são otimizados, evitam insatisfação. Entretanto quando existe uma otimização dos fatores de motivação, geralmente provocam satisfação. (SILVA, 2001)

Na opinião de Herzberg (1968 apud RODRIGUES, 2008, p. 46), os fatores motivacionais deveriam ser implantados nas organizações a partir do "enriquecimento do cargo”, o que supõe enriquecer a tarefa, proporcionando oportunidades para o desenvolvimento psicológico do empregado. Segundo Bernhardt e Pereira (2008):

Foi Herzberg que, introduziu o conceito de "enriquecimento de cargo" criando assim uma das primeiras premissas da QVT: não só recompensar o funcionário com melhor desempenho, mas fazê-lo sentir-se, em tempo integral, como parte importante e determinante de um processo maior e mais complexo dentro da organização.

Surge a Qualidade de Vida no Trabalho, termo que de acordo com RODRIGUES (2005), está sempre voltada para facilitar ou trazer satisfação e bem-estar ao trabalhador na execução da tarefa.

Com essas teorias formou-se a base conceitual para servir de suporte às novas teorias sobre o comportamento do indivíduo no desenvolvimento do seu trabalho e de sua Qualidade de Vida no Trabalho. 


\subsection{A evolução do conceito de QVT (Qualidade de Vida no Trabalho)}

Em 1950, Eric Trist e colaboradores (RODRIGUES, 2008, p. 76), “desenvolveram uma série de estudos que deram origem a uma abordagem sociotécnica em relação à organização do trabalho, tendo como base a satisfação do trabalhador no trabalho e em relação a ele”. Esse novo modelo que agrupa o trinômio Indivíduo/Trabalho/Organização, recebeu a denominação de Qualidade de Vida no Trabalho (QVT). Em 1960, nos Estados Unidos, Louis Davis e colaboradores realizavam pesquisas para "modificar as linhas de montagens, no intuito de tornar a vida dos operários no trabalho mais agradável e satisfatória” (HUSE; CUMMINGS, 1985 apud RODRIGUES, 2008, p. 77). Intensifica-se o conceito de QVT.

Nos Estados Unidos este período é marcado por fatos significativos, dentre os mais importantes, podemos citar: a criação da "National Comission on Productivity", que teve como função analisar as causas da baixa produtividade nas indústrias norteamericanas; a criação pelo congresso do "National Center for Procuctivity and Quality of Working Life”, que tinha como função realizar estudos e servir de laboratório sobre a produtividade e a qualidade de vida do trabalhador e nas atividades de produção e a criação de grupos de estudo da Qualidade de Vida no Trabalho. (HUSE; CUMMINIGS, 1985 apud RODRIGUES, 2008, p. 77)

No início dos anos 70, com a crise energética e alta inflação que acometeram as grandes potências do Ocidente, tivemos uma desaceleração nos rumos da QVT. Em 1979, uma nova fase no desenvolvimento da QVT, dessa vez liderada pelo Japão, que superou a crise com o método japonês de gerenciamento. Ouchi (1982 apud RODRIGUES, 2008, p. 78), com sua Teoria Z, afirma que “o Japão conseguiu manter uma ética de trabalho, ao passo que os americanos se tornaram moles, preguiçosos e se julgavam com direito à boa vida sem ganhá-la”. Diante desse quadro, empresários e administradores norte-americanos precipitaram-se em copiar o método japonês de gerenciamento. De acordo com Peters \& Waterman (1983, apud RODRIGUES, 2008, p. 79), oito atributos seriam a base para um programa de produtividade organizacional e melhor Qualidade de Vida no Trabalho: “Uma firme disposição para agir; maior aproximação do cliente; autonomia e iniciativa dos trabalhadores; produtividade através dos trabalhadores; orientação por valores-filosofia organizacional; limitar-se ao 
desconhecido; formas de trabalho simples e em pequenos grupos; e política administrativa flexível”.

Sintetizando a evolução da QVT, Nadler \& Lawler (1983 apud RODRIGUES, 2008, p. 81), apresentam o quadro a seguir:

\begin{tabular}{lll}
\hline PERÍODO & FOCO & DEFINIÇÃO \\
& PRINCIPAL &
\end{tabular}

\begin{tabular}{|c|c|c|}
\hline $1959 / 1972$ & Variável & $\begin{array}{l}\text { A QVT foi tratada como reação individual ao } \\
\text { trabalho ou às conseqüências pessoais de } \\
\text { Experiência do trabalho. }\end{array}$ \\
\hline
\end{tabular}

\begin{tabular}{|c|c|c|}
\hline $1969 / 1975$ & Abordagem & $\begin{array}{l}\text { A QVT dava ênfase ao indivíduo antes de dar } \\
\text { ênfase aos resultados organizacionais, mas ao } \\
\text { mesmo tempo era vista como um elo dos proje- } \\
\text { tos cooperativos do trabalho gerencial. }\end{array}$ \\
\hline 1972/1975 & Método & $\begin{array}{l}\text { A QVT foi o meio para o engrandecimento } \\
\text { do ambiente de trabalho e a execução de maior } \\
\text { produtividade e satisfação. }\end{array}$ \\
\hline $1975 / 1980$ & Movimento & $\begin{array}{l}\text { A QVT como movimento visa a utilização dos } \\
\text { termos “gerenciamento participativo” e “demo- } \\
\text { cracia industrial” com bastante freqüência, } \\
\text { invocador como ideais do movimento. }\end{array}$ \\
\hline 1979/1983 & Tudo & $\begin{array}{l}\text { A QVT é vista como um conceito global e } \\
\text { como uma forma de enfrentar os problemas de } \\
\text { qualidade e produtividade. }\end{array}$ \\
\hline Previsão futura & Nada & $\begin{array}{l}\text { A globalização da definição trará como conse- } \\
\text { quência inevitável a descrença de alguns auto- } \\
\text { res sobre o termo QVT. E para estes, QVT } \\
\text { nada representará. }\end{array}$ \\
\hline
\end{tabular}

Quadro 1: Definições evolutivas da QVT na visão de Nadler \& Lawler.

Numa definição que aproxima os constructos de satisfação no trabalho e Qualidade de Vida no Trabalho, Morin \& Morin (apud DANTAS; MEDEIROS, 2005), QVT pode ser definida como,

Um constructo multidimensional geralmente referente à satisfação geral com a vida no trabalho e com o equilíbrio entre trabalho e vida pessoal, um sentimento de pertencimento ao grupo de trabalho, uma sensação de tornar-se a si mesmo e de ser valorizado e respeitado.

Minayo, Harzt e Buss (2000) vêem a qualidade de vida como um estado particularmente próprio do ser humano. Algo como a satisfação, que pode ser considerada uma sensação aprazível, que ocorre quando tudo está bem. E esse estado de contentamento, alegria é a condição de satisfação do homem. 


\subsection{Teoria das Características do Trabalho de Hackman e Oldham}

A Teoria das Características do Trabalho de Hackman e Oldham tem como base “a crença de que as pessoas podem ser motivadas pela natureza intrínseca das tarefas de um trabalho”. (SPECTOR, 2005). Quando o trabalho é interessante e agradável, as pessoas gostarão dele, estarão motivadas e terão um bom desempenho.

As características do trabalho induzem a três estados psicológicos que levam à satisfação, à motivação e ao desempenho. São estes:

- Variedade das habilidades, identidade da tarefa e importância da tarefa, fatores que - levam à experiência do significado do trabalho;

- Autonomia, que leva ao sentimento de responsabilidade e

- Feedback, que leva ao conhecimento dos resultados.

Segundo Spector (2005), esses fatores psicológicos são importantes para satisfação e motivação dos funcionários. "Quando o trabalho os induz, os indivíduos se motivados e satisfeitos e têm um desempenho melhor”.

Existe ainda uma última parte da teoria, a força da necessidade de crescimento, uma variável da personalidade, que segundo Spector (2005).

Se refere ao nível de necessidade de uma pessoa por coisas que podem ser obtidas como resultado de um trabalho complicado, tais como crescimento, autonomia e uma sensação de realização. De acordo com Hackman e Oldham, a conexão entre características do trabalho e estados psicológicos nos resultados acontece principalmente em indivíduos com altos níveis de força da necessidade de crescimento.

\subsection{A Satisfação no Trabalho}

Segundo Spector (2005), a satisfação no trabalho é uma variável de atitude que mostra como as pessoas se sentem em relação ao trabalho que têm, seja no todo, seja em relação a alguns de seus aspectos. "É o quanto as pessoas gostam do trabalho delas. A insatisfação no trabalho é o quanto não gostam”.

Archer (1990, apud SILVA JÚNIOR, 2001) define “o motivo como sendo uma necessidade atuando sobre o intelecto, o que leva a pessoa a agir”. Ele afirma que "a motivação é uma tomada de direção para a ação e origina-se de um motivo 
(necessidade)”. Neste contexto, “a satisfação ocorre com o atendimento ou a eliminação de uma necessidade”. Na sua opinião, “motivador e fator de satisfação são antítese.”

Ainda de acordo com Spector (2005), para o estudo da satisfação no trabalho existem duas abordagens - a abordagem global, que considera a satisfação no trabalho como um sentimento único e global em relação ao trabalho, e a abordagem em facetas, ou aspectos. Nesta abordagem, uma pessoa apresenta diferentes níveis de satisfação em relação às várias facetas.

No presente estudo as facetas são as dimensões da satisfação no trabalho, como veremos mais adiante.

De acordo com Spector (2005), a satisfação no trabalho é avaliada perguntandose às pessoas como elas se sentem em relação ao seu trabalho, por meio de questionários ou entrevistas. Várias escalas de trabalho podem ser utilizadas em um questionário. A presente pesquisa sobre satisfação no trabalho foi por meio de questionários e a escala utilizada foi a EST (Escala de Satisfação no Trabalho).

O Índice Descritivo do Trabalho, de acordo com Spector (2005) tem sido a escala de satisfação no trabalho mais popular entre os pesquisadores. Esta escala, tal qual a EST (Escala de Satisfação no Trabalho), avalia 5 facetas ou dimensões da satisfação no trabalho, que são: trabalho, supervisão, salário, colegas de trabalho e oportunidades de promoção.

Acredita-se que certos comportamentos importantes no trabalho sejam resultado da satisfação ou da insatisfação no trabalho. Definidos como Efeitos Potenciais da Satisfação no Trabalho, três desses comportamentos têm se mostrado proeminentes na literatura: desempenho no trabalho, rotatividade e ausência do funcionário.

- $\quad$ Satisfação e Desempenho

Spector (2005, p. 344) cita como resultado de uma completa metanálise de 312 estudos, uma correlação média entre satisfação geral e desempenho no trabalho de 0,20. Como a maioria dos desses estudos se baseia nas pontuações de desempenho dadas pelos supervisores, e eles frequentemente cometem erros de pontuação, isso pode produzir uma falta de precisão nas pontuações de desempenho. Portanto as relações entre satisfação e o desempenho seriam maiores se fossem utilizadas medidas mais precisas.

A relação entre o desempenho e a satisfação no trabalho está clara, porém existem duas explicações opostas para tal. A primeira, segundo Spector (2005), é que a satisfação resulta em desempenho, ou seja, quando as pessoas gostam do seu trabalho, 
se empenharão mais e como conseqüência terão um desempenho melhor. A segunda, de acordo com o autor, é que o desempenho resulta em satisfação, isto é, quando as pessoas tem um bom desempenho, elas tendem a se beneficiar e os benefícios poderão aumentar a satisfação.

Robbins (2002, p. 75), resume da seguinte forma, “embora não possamos dizer que um funcionário feliz é mais produtivo, podemos afirmar que as organizações felizes são mais produtivas”.

- Satisfação no Trabalho e Rotatividade

Muitos estudos relacionaram a demissão ou rotatividade à satisfação no trabalho. "Muitos estudos têm demonstrado que funcionários insatisfeitos apresentam maior probabilidade de demitir-se de seus empregos do que os satisfeitos”. (CRAMPTON; WAGNER, 1994, apud SPECTOR, 2005).

A maior parte dos estudos nesse aspecto trabalha da seguinte forma: avalia a satisfação no trabalho de uma amostra de funcionários, espera um período de tempo para ver quem pede demissão. Dessa forma chega-se a conclusão que "a insatisfação é um fator que leva os funcionários a desistir de seus empregos.” (SPECTOR, 2005)

Segundo Robbins (2002), a satisfação está negativamente relacionada com a rotatividade. Existem outros fatores que influenciam a rotatividade, como as condições de mercado, as expectativas quanto às oportunidades no emprego e o tempo de casa.

- Insatisfação no Trabalho e Ausência

A ausência, de forma geral não apresenta forte relação com a satisfação no trabalho. "Uma possível razão para a pequena correlação entre satisfação e ausência é que a pessoa pode se ausentar por muitas razões”. E desse leque de razões, umas podem estar associadas à satisfação e outras não. (KOHLER; MATHIEU, 1993 apud SPECTOR, 2005)

A relação encontrada entre essas variáveis é negativa, porém moderada, de acordo com Robbins (2002).

A saúde e o bem-estar, segundo Spector (2005), merecem atenção quando relacionadas a satisfação no trabalho. Muitos psicólogos organizacionais estudam a possibilidade de a insatisfação estar relacionada com a saúde e bem-estar do funcionário. Existem afirmações no sentido de que a satisfação no trabalho poderia ser um fator causador de doenças.

“Alguns estudos correlacionais demonstram que a satisfação no trabalho tem relação com variáveis da saúde”. (SPECTOR, 2005, p. 347) 
"Estudos descobriram que funcionários insatisfeitos relataram mais sintomas físicos, como problemas para dormir e dores estomacais, do que seus companheiros satisfeitos”. (BEGLEY; CZAJKA, 1993 apud SPECTOR, 2005). De acordo com Jex \& Gudanowski (1992 apud SPECTOR, 2005) descobriu-se também a correlação entre insatisfação e emoções negativas no trabalho, como ansiedade e depressão. Segundo SPECTOR (2005), esses estados emocionais negativos podem ser considerados indicadores da condição do bem-estar no trabalho.

De acordo com Spector (2005) existem características do trabalho que contribuem para a satisfação no trabalho. Cinco delas fazem parte da teoria das características do trabalho, de Hackman e Oldham:

- Variedade de habilidade, que seria o número de diferentes habilidades diferentes necessárias para a realização do trabalho;

- Identidade da tarefa, ou seja, se um funcionário faz todo o trabalho ou apenas parte dele;

- Significado da tarefa, que seria o impacto que o trabalho tem sobre outras pessoas;

- Autonomia, que seria a liberdade que os funcionários têm para fazer seu trabalho da forma como acharem melhor;

- Feedback da tarefa, ou seja, o quanto está claro para os funcionários que eles estejam fazendo seu trabalho corretamente

Dezenas de estudos sobre muitos tipos diferentes de trabalho mostraram que cada uma das cinco características tem relação cm a satisfação no trabalho.

\subsection{Medidas para investigação da Satisfação no Trabalho}

De acordo com a literatura aqui estudada, vários são os modelos estatísticos para medir a satisfação no trabalho, dependendo das variáveis enfatizadas.

Spector (2005, p. 365) citou a pesquisa realizada na Universidade do Sul da Flórida, em 1983, sobre a satisfação para o trabalho no corpo de bombeiros do Município. Naquele momento, a combinação de um novo chefe de brigada e o congelamento dos salários por dois anos levaram a uma insatisfação generalizada entre os bombeiros. O início da pesquisa se deu com entrevistas a diversos grupos de 
funcionários. Com as respostas foi elaborado um questionário de satisfação adequado à organização. Em seguida foi feita a pesquisa com todos os bombeiros utilizando esse questionário e descobriram que o nível de satisfação era bastante baixo, em especial em relação ao salário e a comunicação. Os resultados foram compilados em um relatório que foi entregue ao sindicato, que utilizou o relatório em uma bem sucedida campanha por maiores salários e melhor comunicação. Um ano mais tarde a pesquisa foi repetida, e descobriu-se que o nível de satisfação no trabalho havia melhorado e constatou-se aumentos significativos nos segmentos salário e comunicação.

Num estudo de caso sobre a satisfação e motivação dos servidores no Serviço Público, Gomes e Quelhas (2003), adotaram duas linhas de interpretação, uma fundamentada da teoria das necessidades de Maslow e outra, na teoria da motivaçãohigiene de Herzberg. Os resultados da pesquisa indicaram, no que se refere às necessidades humanas um grau médio global de satisfação dos servidores igual a 3,5, numa escala de 1 a 6 . As necessidades de segurança e as fisiológicas apresentaram resultados mais baixos, 3,24 e 3,26, o que sugere que o atendimento a essas necessidades é o mais prioritário. Em relação aos fatores higiênicos e motivadores, a média global foi igual a 3,47, e numa analise detalhada, concluiu-se que quanto à motivação para o trabalho, a realização é o que mais contribui para motivar os servidores e o progresso funcional e crescimento pessoal são os que menso contribuem.

Dantas e Medeiros (2005) realizaram um estudo visando analisar a satisfação no trabalho de uma organização pública de ensino superior, através da adaptação do modelo proposto por Walton, que é composto por 8 dimensões que afetariam significativamente o trabalhador em seu ambiente de trabalho. Os resultados indicam um quadro geral de insatisfação no trabalho. Os itens relativos a dimensão compensação justa e adequada foram todos percebidos como insatisfatórios.

Buss (2002 apud SILVA, 2007) investigou as dimensões que mais caracterizam a qualidade de vida no trabalho, segundo a percepção do corpo técnico e auxiliar administrativo de uma Universidade Catarinense. Os resultados mostraram que as pessoas sentem a necessidade de ser valorizadas e reconhecidas pelo trabalho que realizam; preferem trabalhar em equipe, formando times de trabalho que geram pluralidade de idéias e cumplicidade; apontaram o respeito como importante para a qualidade de vida no trabalho. Por outro lado, o salário injusto gera insatisfação e reflete na qualidade de vida no trabalho. 


\section{CARACTERÍSTICAS DA ORGANIZAÇÃO ESTUDADA}

Criado pela Constituição Federal de 1988, o Superior Tribunal de Justiça (STJ) é a corte responsável por uniformizar a interpretação da lei federal em todo o Brasil, seguindo os princípios constitucionais e a garantia e defesa do Estado de Direito.

O STJ começou a funcionar em abril de 1989 - ano em que julgou pouco mais de três mil processos. Em 1995 o Tribunal ganhou nova sede e viu seu número de julgados crescer quase exponencialmente. Em 2000 o número de julgados ultrapassou a casa dos cento e cinqüenta mil processos e em 2008 passou de trezentos e cinqüenta mil.

Uma prestação acessível, rápida e efetiva, missão do Superior Tribunal de Justiça, requer um comportamento participativo de todos os servidores. A necessidade de servidores satisfeitos e com qualidade de vida no trabalho passa a ser uma grande preocupação da organização. Uma ação gerencial eficaz precisa estar embasada em informações que indiquem o efetivo grau de satisfação ou insatisfação dos servidores no que se refere às diversas ocorrências e situações que os afetam no dia-a-dia da sua atividade profissional e da sua relação empregatícia, o que significa que é necessário haver um diagnóstico do nível de satisfação dos servidores do Superior Tribunal de Justiça.

\section{METODOLOGIA}

\subsection{Tipo de pesquisa}

Utilizando-se o critério de classificação proposto por Vergara (2000), pode-se qualificar a presente pesquisa em relação a dois aspectos: quanto aos fins e quanto aos meios de investigação.

Quanto aos fins, a presente pesquisa é exploratória, descritiva e aplicada. Descritiva porque compreende a obtenção e exposição de dados representativos de determinado fenômeno. Neste caso, descreve-se a percepção dos servidores do Superior Tribunal de Justiça acerca da satisfação no trabalho. Ainda quanto aos fins, a pesquisa é 
aplicada, pois possui finalidade prática, na medida em que se busca identificar a existência de correlação entre as variáveis, o que pode contribuir para a gestão de pessoas na instituição.

No que se refere aos meios de investigação, a presente pesquisa é bibliográfica, de campo e estudo de caso. Bibliográfica uma vez que compreende uma revisão da literatura acerca do tema, construída a partir do estudo de material publicado em livros, artigos, entre outros. Ainda quanto aos meios, a pesquisa é de campo já que foi feita uma investigação empírica junto aos servidores da instituição objeto de estudo. A pesquisa também é um estudo de caso porque está circunscrita à instituição objeto de estudo.

\subsection{População e Amostra}

A pesquisa será realizada com servidores do Superior Tribunal de Justiça, onde trabalham atualmente 2.604 servidores entre auxiliares, técnicos e analistas judiciários distribuídos em diversas secretarias e gabinetes.

Desta população, entretanto, para fins de pesquisa, optou-se por investigar apenas uma amostra (parte representativa da referida população), de caráter não probabilístico, seguindo o critério de acessibilidade e dentre servidores da Secretaria Judiciária, Secretaria dos Órgãos Julgadores, Gabinetes e Área Administrativa. Constituem, portanto, público-alvo da presente pesquisa os servidores lotados nesses locais e que livremente concordem em participar.

Considera-se unidade de pesquisa o servidor lotado em um dos locais acima definidos, de qualquer nível de escolaridade, ocupantes de cargos ou em funções comissionadas. 


\subsection{Instrumento utilizado}

O instrumento utilizado na pesquisa, a Escala de Satisfação no Trabalho (EST), é uma escala multidimensional composta de 25 itens que visam medir as seguintes dimensões da satisfação com trabalho:

-satisfação com os colegas de trabalho: contentamento com a colaboração, a amizade, a confiança e o relacionamento mantido com os colegas de trabalho;

-satisfação com o salário: contentamento com o que recebe como salário se comparado com o quanto o indivíduo trabalha, com sua capacidade profissional, com o custo de vida e com os esforços feitos na realização do trabalho;

- satisfação com a chefia: contentamento com a organização e a capacidade profissional do chefe, com o seu interesse pelo trabalho dos subordinados e entendimento entre eles;

- satisfação com a natureza do trabalho: contentamento com o interesse despertado pelas tarefas, com a capacidade destas em absorver o trabalhador e com a variedade das mesmas;

- satisfação com as promoções: contentamento com o número de vezes que já recebeu promoções, com as garantias oferecidas a quem é promovido, com a maneira como a instituição realiza promoções e com o tempo de espera pelas mesmas.

A Escala de Satisfação no Trabalho (EST) permite avaliar o grau de satisfação de um empregado em relação às cinco dimensões assim representadas:

- Satisfação com os colegas de trabalho (itens 1, 6, 14, 17, 24)

- Satisfação com o salário (itens 5, 8, 12, 15, 21)

- Satisfação com a cheia (itens 2, 9, 19, 22, 25)

- Satisfação com a natureza do trabalho (itens $7,11,13,18,23$ )

- Satisfação com as promoções (itens 3, 4, 10, 16, 20)

O cômputo do escore médio de cada uma das cinco dimensões será obtido separadamente somando-se os valores indicados pelo respondente de cada item e dividindo-se esse valor pela quantidade de itens da dimensão. Assim, para saber o valor do escore médio da dimensão "satisfação com a chefia" somam-se os valores dos itens 2, 9, 19, 22, 25 e divide-se por 5. 


\subsection{Procedimentos de coleta e análise dos dados}

Os dados foram coletados por meio da aplicação do questionário validado EST (Escala de Satisfação no Trabalho). O questionário foi aplicado dentre servidores do Superior Tribunal de Justiça, lotados na Secretaria dos Órgãos Julgadores, Secretaria Judiciária, Gabinetes e Área administrativa, seguindo o critério de acessibilidade.

A escala utilizada (EST) utiliza os seguintes tipos de variáveis: variável ordinal, para resposta aos itens/dimensões, tipo Likert, variando de 1 a 7 (do totalmente insatisfeito ao totalmente satisfeito); variável nominal (sexo, escolaridade, área de atuação, cargo, função comissionada) e variável numérica intervalar (tempo de serviço e idade).

As respostas dos participantes ao instrumento foram registradas em um arquivo de dados eletrônico no programa SPSS (Statistical Package for the Social Science), versão 10.0 .

Os dados foram inseridos sem erros de digitação, não foram encontrados mais de 1\% de dados omissos em qualquer variável e o tamanho da amostra foi de 71servidores do Superior Tribunal de Justiça.

Em seguida, iniciaram-se as análises descritivas de cada variável do instrumento de medida utilizado. Realizaram-se análises das médias, desvios padrão mínimo e máximo das seguintes variáveis:

1 - Com o espírito de colaboração dos meus colegas de trabalho;

2 - Com o modo como meu chefe organiza o trabalho no meu setor;

3 - Com o número de vezes que já fui promovido nesta instituição;

4 - Com as garantias que a instituição oferece a quem é promovido;

5 - Com o meu salário comparado com o quanto eu trabalho;

6 - Com o tipo de amizade que meus colegas demonstram por mim;

7 - Com o grau de interesse que minhas tarefas despertam;

8 - Com o meu salário comparado à minha capacidade profissional;

9 - Com o interesse de meu chefe pelo meu trabalho;

10 - Com a maneira como esta instituição realiza promoções de seu pessoal;

11 - Com a capacidade de meu trabalho absorver-me;

12 - Com o meu salário comparado ao custo de vida;

13 - Com a oportunidade de fazer o tipo de trabalho que faço; 
14 - Com a maneira como me relaciono com meus colegas de trabalho;

15 - Com a quantia em dinheiro que eu recebo desta instituição ao final de cada mês

16 - Com as oportunidades de ser promovido nesta instituição

17 - Com a quantidade de amigos que eu tenho entre meus colegas de trabalho

18 - Com as preocupações exigidas pelo meu trabalho

19 - Com o entendimento entre eu e meu chefe

20 - Com o tempo que eu tenho de esperar para receber uma promoção nesta instituição

21 - Com o meu salário comparado aos meus esforços no trabalho

22 - Cm a maneira como meu chefe me trata

23 - Com a variedade de tarefas que realizo

24 - Com a confiança que eu posso ter em meus colegas de trabalho

25 - Com a capacidade profissional do meu chefe

\section{RESULTADOS E DISCUSSÃO}

Nesta seção são apresentados os resultados descritivos da amostra e de cada variável do presente estudo. Discute-se, também, as correlações entre as variáveis que constituem a presente pesquisa.

\subsection{Descrição da Amostra}

As características da amostra referentes ao sexo dos participantes, cargo de ocupação, idade, nível de escolaridade e tempo de serviço na empresa, são apresentadas a seguir.

\begin{tabular}{|c|c|c|c|c|c|}
\hline VARIÁVEL & $\mathrm{F}$ & $\%$ & VARIÁVEL & $\mathbf{F}$ & $\%$ \\
\hline Sexo & & & \multicolumn{3}{|l|}{ Área que trabalha } \\
\hline Masculino & 50 & 70,4 & Administrativa & 20 & 28,2 \\
\hline Feminino & 20 & 28,2 & Judiciária & 28 & 39,4 \\
\hline
\end{tabular}




\begin{tabular}{|c|c|c|c|c|c|}
\hline Omissos & 1 & 1,4 & Órgãos Julgadores & 11 & 15,5 \\
\hline \multicolumn{3}{|l|}{ Faixa etária } & Gabinete & 11 & 15,5 \\
\hline De 18 a 25 anos & 7 & 9,9 & Omissos & 1 & 1,4 \\
\hline De 26 a 33 anos & 19 & 26,8 & Tempo que trabalha no STJ & & \\
\hline De 34 a 41 anos & 19 & 26,8 & Menos de 01 ano & 3 & 4,2 \\
\hline De 42 a 49 anos & 18 & 25,4 & De 01 a 05 anos & 24 & 33,8 \\
\hline De 50 a 57 anos & 5 & 7,0 & De 06 a 10 anos & 12 & 16,9 \\
\hline De 58 a 65 anos & 2 & 2,8 & De 11 a 15 anos & 12 & $\overline{16,9}$ \\
\hline Omissos & 1 & 1,4 & De 16 a 20 anos & 11 & 15,5 \\
\hline Estado Civil & & & De 21 a $25 n o s$ & 5 & 7,0 \\
\hline Solteiro & 22 & 31,0 & De 26 a 30 anos & 3 & 4,2 \\
\hline Casado & 35 & 49,3 & Omissos & 1 & 1,4 \\
\hline Separado-Divorciado & 11 & 15,5 & $\begin{array}{l}\text { Ocupa função de confiança ou } \\
\text { cargo em Comissão (FC ou CJ) }\end{array}$ & & \\
\hline Outros & 2 & 2,8 & Não ocupo & 34 & 47,9 \\
\hline Omissos & 1 & 1,4 & FC 2 & 3 & 4,2 \\
\hline Nível de Escolaridade & & & FC 4 & 8 & $\overline{11,3}$ \\
\hline Ensino Médio (2º grau) & 2 & 2,8 & FC 5 & 5 & 7,0 \\
\hline Superior incompleo & 9 & 12,7 & FC 6 & 11 & 15,5 \\
\hline Superior completo & 34 & 47,9 & CJ 1 & 1 & 1,4 \\
\hline Especialização & 24 & 33,8 & CJ 2 & 5 & 7,0 \\
\hline Pós-Doutorado & 1 & 1,4 & CJ 3 & 3 & 4,2 \\
\hline Omissos & 1 & 1,4 & Omissos & 1 & 1,4 \\
\hline
\end{tabular}

Tabela 1: Características da amostra

A maioria da amostra é composta por participantes do sexo masculino (50\%), casados (49,3\%) que possuem de 26 a 41 anos de idade (53,6\%). Em relação ao nível de escolaridade e tempo de serviço na empresa, grande parte dos respondentes possui nível superior completo (47,9\%) e está há menos de 5 anos no órgão (33,8\%).

Quanto aos cargos ocupados no Superior Tribunal de Justiça, em relação a amostra, grande parte dos servidores estão lotados na Secretaria Judiciária (39,4\%), seguidos pela Área Administrativa (28,2\%). Dos 71 respondentes, 48 (67,6\%) são técnicos judiciários enquanto apenas 3 (4,2 \%) são analistas administrativos. Este dado nos permite concluir que na área administrativa trabalham muitos técnicos judiciários, uma vez que no nosso universo temos 20 respondentes da área administrativa e apenas 03 analistas administrativos. Com relação ao cargo em comissão, 47,9\% dos respondentes não ocupam função de confiança e a maioria dos ocupantes possui a Função de Confiança 6 (FC 6), o que nos permite concluir que temos em nossa amostra 
alguns chefes de seção, uma vez que a FC 6 é uma função característica de chefes de seção/setor.

\subsection{Descrição da Escala de Satisfação no Trabalho}

Na Tabela 2 é possível observar os resultados descritivos quanto a Escala de Satisfação no Trabalho realizada junto aos servidores do STJ. A EST é uma medida multidimensional, construída e validada com o objetivo de avaliar o grau de contentamento do trabalho frente aos 25 itens que compõem o questionário. Os servidores avaliaram os aspectos atuais do trabalho utilizando uma escala de freqüência que apresenta os pontos: 1 = Totalmente insatisfeito; 2 = Muito insatisfeito; $3=$ Insatisfeito; 4 = Indiferente; $5=$ Satisfeito, $6=$ Muito Satisfeito e $7=$ Totalmente Satisfeito.

A interpretação dos resultados deverá considerar que quanto maior for o valor do escore médio maior será o grau de contentamento ou satisfação do empregado com aquele aspecto do seu trabalho. Assim, valores entre 5 e 7 tendem a indicar satisfação. Por outro lado, valores entre 1 e 3,9 tendem a sinalizar insatisfação, enquanto valores entre 4 e 4,9 informam um estado de indiferença, ou seja, nem satisfeito, nem insatisfeito.

\begin{tabular}{|c|c|c|c|c|c|}
\hline ITENS & $\mathbf{N}$ & MíNIMO & MÁXIMO & MÉDIA & DESVIO PADRÃO \\
\hline $\begin{array}{l}1 \text { - Com o espirito de colaboração dos meus } \\
\text { colegas de trabalho }\end{array}$ & 71 & 1 & 7 & 5,30 & 1,367 \\
\hline $\begin{array}{l}2 \text { - Com o modo como meu chefe organiza o } \\
\text { trabalho no meu setor }\end{array}$ & 71 & 1 & 7 & 5,20 & 1,203 \\
\hline $\begin{array}{l}3 \text { - Com o número de vezes que já fui } \\
\text { promovido nesta instituição }\end{array}$ & 71 & 1 & 7 & 4,86 & 1,486 \\
\hline $\begin{array}{l}4 \text { - Com as garantias que a instituição oferece a } \\
\text { quem é promovido }\end{array}$ & 71 & 1 & 7 & 4,14 & 1,323 \\
\hline $\begin{array}{l}5 \text { - Com o meu salário comparado com o quanto } \\
\text { eu trabalho }\end{array}$ & 71 & 2 & 7 & 5,04 & 1,176 \\
\hline $\begin{array}{l}6 \text { - Com o tipo de amizade que meus colegas } \\
\text { demonstram por mim }\end{array}$ & 71 & 2 & 7 & 5,51 & 1,120 \\
\hline $\begin{array}{l}7 \text { - Com o grau de interesse que minhas tarefas } \\
\text { me despertam }\end{array}$ & 71 & 1 & 7 & 4,80 & 1,400 \\
\hline $\begin{array}{l}8 \text { - Com o meu salário comparado à minha } \\
\text { capacidade profissional }\end{array}$ & 71 & 1 & 7 & 4,51 & 1,620 \\
\hline
\end{tabular}


9 - Com o interesse de meu chefe pelo meu trabalho

10 - Com a maneira como esta instituição realiza promoções de seu pessoal

11 - Com a capacidade de meu trabalhoabsorver-me

12 - Com o meu salário comparado ao custo de vida

13 - Com a oportunidade de fazer o tipo de trabalho que faço

14 - Com a maneira como me relaciono com meus colegas de trabalho

15 - Com a quantia em dinheiro que eu recebo desta instituição ao final de cada mês

16 - Com as oportunidades de ser promovido nesta instituição entre meus colegas de trabalho

18 - Com as preocupações exigidas pelo meu trabalho

19 - Com o entendimento entre eu e meu chefe

20 - Com o tempo que eu tenho de esperar para receber uma promoção nesta instituição

21 - Com o meu salário comparado aos meus esforços no trabalho

22 - Com a maneira como meu chefe me trata

23 - Com a variedade de tarefas que realizo

24 - Com a confiança que eu posso ter em meus

colegas de trabalho

25 - Com a capacidade profissional do meu chefe

N (Número de questionários válidos)
17 - Com a quantidade de amigos que eu tenho

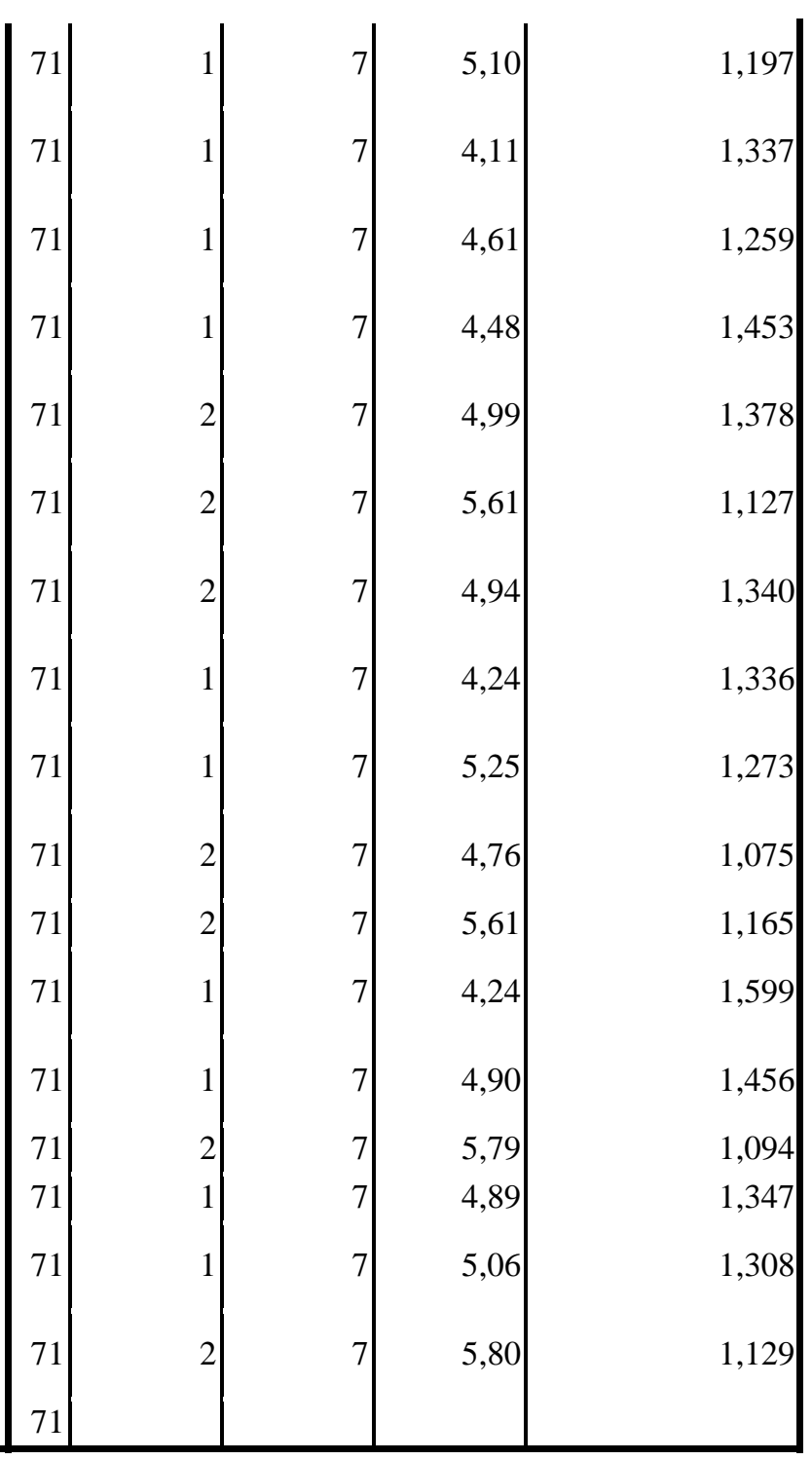

Tabela 2: Resultados descritivos da Escala de Satisfação no Trabalho (EST)

As médias variaram de 4,11 a 5,80, numa escala que variava de 1 (totalmente insatisfeito) a 7 (totalmente satisfeito), o que indica, de forma geral, que os servidores estão variando de indiferentes a satisfeitos com o trabalho. Nesta escala de 7 pontos, foram considerados altos os desvios padrão acima de 1,31. Nesta variável, 19 valores de desvios padrão ultrapassaram esse valor, indicando que, na maioria das percepções em relação a satisfação no trabalho, os servidores comportam-se de maneira heterogênea.

O item 18 (com as preocupações exigidas pelo meu trabalho) obteve o menor desvio padrão $(1,075)$ e uma média de 4,76 , o que significa que os servidores de uma forma geral, se sentem indiferentes, ou seja, nem satisfeito, nem insatisfeito com as preocupações exigidas pelo trabalho. 
A maior média ocorreu no item 25 (com a capacidade profissional do meu chefe), 5,80 e como o desvio padrão foi baixo - 1,129 - podemos concluir que os servidores estão satisfeitos com a capacidade profissional de seus chefes. O item 19 (com o entendimento entre eu e meu chefe) obteve média 5,61 e desvio padrão 1,165, demonstrando que os servidores estão satisfeitos com esse entendimento. Apresentando também uma média alta e um desvio padrão baixo, o item 22 (com a maneira como meu chefe me trata) demonstrou que os servidores estão satisfeitos com este quesito. Esses resultados mostram que os chefes estão bem preparados e aptos a exercerem tais funções, tanto profissionalmente como no quesito interpessoal.

Por outro lado a menor média, 4,11 no item 10 (com a maneira como esta instituição realiza promoções de seu pessoal) demonstra uma indiferença dos servidores quando o assunto é a promoção. Complementando esse dado, a segunda menor média, 4,14 foi no item 4 (com as garantias que a instituição oferece a quem é promovido) sugerindo que existe uma indiferença por parte dos servidores neste aspecto. Os itens 16 (com as oportunidades de ser promovido nesta instituição) e 20 (com o tempo que eu tenho de esperar para receber uma promoção nesta instituição) obtiveram médias iguais - 4,24 - sugerindo uma indiferença em relação a esses aspectos, embora haja uma certa heterogeneidade nesses itens. O processo de promoção como um todo merece uma atenção especial instituição.

\subsection{Descrição das Dimensões da Satisfação com o Trabalho}

Nas Tabela 3 é possível observar os resultados descritivos quanto as Dimensões da Satisfação com o Trabalho. As respostas foram agregadas por dimensões da seguinte forma:

- $\quad$ Satisfação com os colegas de trabalho (itens 1, 6, 14, 17 e 24 da EST)

- $\quad$ Satisfação com o salário (itens 5, 8, 12, 15 e 21 da EST)

- $\quad$ Satisfação com a chefia (itens 2, 9, 19, 22 e 25 da EST)

- $\quad$ Satisfação com a natureza do trabalho (itens 7, 11, 13, 18 e 23 da EST)

- $\quad$ Satisfação com as promoções (itens 3, 4, 10, 16 e 20 da EST)

O cômputo do escore médio de cada uma das cinco dimensões foi obtido separadamente somando-se os valores indicados pelo respondente em cada item e 
dividindo-se esse valor pela quantidade de itens da dimensão. Assim, para saber o valor do escore médio da dimensão "satisfação com a chefia” somam-se os valores dos itens 2, 9, 19, 22 e 25 e divide-se por 5.

\begin{tabular}{|l|r|r|r|r|r|}
\hline \multicolumn{1}{|c|}{ ITENS } & N & Mínimo & Máximo & Média & Desvio Padrão \\
\hline Satisfação com os colegas de & 71 & 2 & 7 & 5,34 & 1,065 \\
trabalho & 71 & 2 & 7 & 4,77 & 1,227 \\
Satisfação com o salário & 71 & 2 & 7 & 5,50 & 0,964 \\
Satisfação com a chefia & 71 & 2 & 7 & 4,81 & 1,021 \\
Satisfação com a natureza do & 71 & 2 & 7 & 4,32 & 1,149 \\
trabalho & 71 & & & \\
Satisfação com as promoções & & & \\
Número de questionários válidos & & & & \\
\hline
\end{tabular}

Tabela 3: Resultados descritivos de Dimensões da Satisfação com o Trabalho

As médias variaram de 4,32, que indica indiferença a 5,50, estado de satisfação, com desvio padrão menor que 1,31 em todas as dimensões, ou seja, indicando homogeneidade do grupo.

Na dimensão "satisfação com os colegas de trabalho", média foi de 5,34 com desvio padrão de 1,065, indicando que os servidores em geral estão satisfeitos com os colegas de trabalho, ou seja, estão satisfeitos com a colaboração, a amizade, a confiança e o relacionamento mantido com os colegas de trabalho.

Ao analisarmos a dimensão "satisfação com o salário”, com uma média de 4,44 e desvio padrão 1,227, podemos inferir que os servidores estão em geral indiferentes, nem satisfeitos nem insatisfeitos, com o que recebem como salário se comparado com o quanto ele trabalha, com sua capacidade profissional, com o custo de vida e com os esforços feitos na realização do trabalho. O item 12 da tabela 2, “com o meu salário comparado ao custo de vida” apresentou a menor média, 4,61, dentre os itens que compõe a dimensão “satisfação com o salário”. Na amostra estudada, quase metade dos servidores não ocupam função de confiança, o que pode explicar em parte essa indiferença, uma vez que os salários recebem um aumento considerável quando somados aos valores percebidos pelas funções de confiança.

A dimensão "satisfação com a chefia" apresentou a maior média e o menor desvio padrão $(\mathrm{M}=5,50$ e $\mathrm{DP}=0,964)$. Os servidores estão satisfeitos com a organização e capacidade profissional do chefe, com o seu interesse pelo trabalho dos subordinados e entendimento entre eles. Os chefes desta instituição estão capacitados emocionalmente e profissionalmente para tal função. Por ser uma instituição pública, o 
mérito é maior, pois indica que o elemento 'político' está sendo substituído por capacidade e aptidão na escolha de suas chefias.

A satisfação com natureza do trabalho, traduzida pelo contentamento com o interesse despertado pelas tarefas, com a capacidade de elas absorverem o trabalhador e com a variedade das mesmas, apresentou uma média de 4,81 com um desvio padrão de 1,021, informando um estado de indiferença por parte dos servidores. O alto volume de trabalho, somado ao tipo de trabalho, quase mecânico em vários setores, contribuem para essa indiferença. Rotinas de trabalho implantadas há muito tempo precisam ser questionadas e reavaliadas.

O contentamento com o número de vezes que o servidor já recebeu promoções, com as garantias oferecidas a quem é promovido, com a maneira de a empresa realizar promoções e com o tempo de espera pela promoção, agrupados na dimensão "satisfação com as promoções” apresentou a menor média, 4,32, com um desvio padrão de 1,149, indicando que os servidores estão em geral indiferentes a esse aspecto.

\section{CONCLUSÕES E RECOMENDAÇÕES}

O presente estudo objetivou investigar o grau de contentamento do servidor do Superior Tribunal de Justiça frente a cinco dimensões teóricas do conceito de Satisfação no Trabalho. Para a consecução deste objetivo principal, foi utilizado um instrumento de pesquisa, construído e validado no Brasil, a EST, Escala de Satisfação no Trabalho, para coletar as respostas dos participantes da pesquisa, a fim de identificar suas percepções acerca da satisfação no trabalho.

Os resultados obtidos no quesito "satisfação com os colegas” e "satisfação com a chefia”, indicando satisfação nesses itens, e no quesito "satisfação com a natureza do trabalho”, indicando indiferença, reforçam a Teoria de Robbins (2002), quando ele diz que “o trabalho de uma pessoa é muito mais do que as atividades óbvias, como organizar papéis, atender clientes ou dirigir um caminhão. $O$ trabalho requer a convivência com os colegas e superiores [...]”. Os servidores do Superior Tribunal de Justiça estão mais satisfeitos com a convivência com os colegas e superiores do que com as tarefas que desempenham. 
Segundo Herzberg (1968 apud RODRIGUES, 2008), “o oposto da satisfação com o trabalho não seria a insatisfação, mas, nenhuma satisfação com ele e igualmente o oposto da insatisfação seria nenhuma insatisfação com o trabalho”. As dimensões “satisfação com o salário”, “satisfação com a natureza do trabalho” e “satisfação com as promoções” apresentaram médias que indicam um estado de indiferença, ou seja, os servidores não estão nem satisfeitos, nem insatisfeitos.

Os fatores higiênicos são os que contribuem para a insatisfação com o trabalho, quais sejam as políticas da empresa, administração, supervisão e remuneração, que quando adequados, tranqüilizam os trabalhadores, segundo a Teoria de Hezrberg. As dimensões "satisfação com o salário" e "satisfação com as promoções” precisam ser estudadas pela instituição, sob pena de contribuírem para a insatisfação com o trabalho. Segundo Herzberg (1968 apud RODRIGUES, 2008), os fatores higiênicos, quando otimizados, evitam a insatisfação. Já a dimensão "satisfação com a chefia”, que de acordo com Hezberg é um fator higiênico, ao apresentar média de 5,50, indicou satisfação. De acordo com Hezberg, este resultado tranqüiliza os servidores.

Ainda de acordo com a Teoria de Herzberg (1968 apud RODRIGUES, 2008) “os fatores que contribuem para a satisfação com o trabalho são os fatores motivadores, como realização, reconhecimento, responsabilidade, o próprio trabalho e progresso ou desenvolvimento”. O pior resultado apresentado foi em relação à satisfação com as promoções, traduzida pela indiferença em relação ao número de vezes que o servidor já recebeu promoções, pelas garantias oferecidas a quem é promovido, pela maneira de a empresa realizar promoções e pelo tempo de espera pela promoção. Tal resultado sugere uma revisão e aprimoramento da política de promoções na instituição.

Ao analisarmos os resultados da dimensão "satisfação com a natureza do trabalho" sob a ótica de Herzberg, fica clara a necessidade de "enriquecer a tarefa, proporcionando oportunidades para o desenvolvimento psicológico do empregado.” Herzberg (1968, apud RODRIGUES, 2008). Os resultados obtidos nesta dimensão melhorariam se a instituição observar o que foi feito em 1960, época em que o conceito de Qualidade de Vida no Trabalho começava a ser intensificado, e Louis Davis e colaboradores realizavam pesquisas para "modificar as linhas de montagens, no intuito de tornar a vida dos operários no trabalho mais agradável e satisfatória” (HUSE; CUMMINGS, 1985 apud RODRIGUES, 2008, p. 77).

De acordo com a Teoria das Características do Trabalho de Hackman e Oldham, “quando o trabalho é interessante e agradável, as pessoas gostarão dele, estarão 
motivadas e terão um bom desempenho.” Dos três estados psicológicos que levam a satisfação no trabalho:

-Variedade das habilidades, identidade da tarefa e importância da tarefa, fatores que levam à experiência do significado do trabalho;

- Autonomia, que leva ao sentimento de responsabilidade e

- Feedback, que leva ao conhecimento dos resultados; dois deles estão comprometidos com o sentimento de indiferença apresentado com a "satisfação com a natureza do trabalho" e "satisfação com as promoções”. Pode-se inferir que a luz dessa Teoria os servidores não se sentem motivados e satisfeitos, o que pode comprometer seu desempenho.

Os resultados obtidos de um modo geral informam um estado de indiferença em relação a três das cinco dimensões da satisfação no trabalho. As médias e desviospadrão encontrados indicam homogeneidade do grupo em relação as cinco dimensões. A "satisfação com a chefia" apresentou a maior média e o menor desvio-padrão, de onde podemos concluir que os chefes no Superior Tribunal de Justiça estão capacitados profissionalmente, têm aptidão para exercerem tal chefia e habilidade na orientação de seus subordinados.

As principais contribuições vão ao encontro de uma melhor compreensão das variáveis que afetam e compõe a satisfação no trabalho. Este trabalho também contribuiu para a identificação das ações de suporte que precisam de mais atenção por parte de gestores da instituição estudada, além de explicitar a opinião dos servidores sobre tais ações.

Algumas recomendações à instituição estudada podem ser feitas. Com base nos resultados, seria importante o desenvolvimento de ações que abordassem os seguintes tópicos: enriquecimento da tarefa; criação de uma política de promoção, com regras claras e mais oportunidades; incentivo ao aperfeiçoamento no trabalho; entre outros.

A pesquisa apresentou limitações que restringem a generalização dos dados para outros contextos, uma vez que foram coletados junto a amostra de pequena escala, representativa apenas do contexto no qual a instituição estudada está inserida.

Os resultados da pesquisa ressaltam a importância de um olhar mais atencioso para as práticas e políticas organizacionais referentes à gestão de pessoas, pois são determinantes para a satisfação no trabalho do servidor, e consequentemente para um melhor desempenho no seu trabalho. Considerando os resultados, as contribuições e as limitações do estudo, pode-se sugerir uma agenda de pesquisa: 
1. realização de mais pesquisas que identifiquem o grau de contentamento/satisfação do servidor frente as dimensões do seu trabalho;

2. utilização de técnicas e procedimentos estatísticos mais sofisticados para garantir maior fidedignidade dos resultados de novos estudos e

3. avaliação do diagnóstico de satisfação no trabalho, para uma melhor compreensão da satisfação do servidor no trabalho. 


\section{REFERÊNCIAS BIBLIOGRÁFICAS}

BERNHARDT, A.; PEREIRA, R. L. A importância da qualidade de vida no trabalho para a empresa no século XXI. Revista de divulgação técnico-científica do ICPG, v. 2, n.6, jul/set. 2008.

CORRÊA, Rossi A. A qualidade de vida, qualidade do trabalho, qualidade do atendimento público e competitividade. Revista de Administração Pública. Rio de Janeiro: FGV, 1993.

DANTAS, A. B.; MEDEIROS, S. A. Avaliação da satisfação no trabalho com o uso de indicadores de qualidade de vida no trabalho. Anais do XXV Encontro Nac. de Eng. De Produção. Porto Alegre, 29 out. a 1 nov. 2005.

FRANÇA, Ana Cristina. Qualidade de vida no trabalho: conceitos, abordagens, inovações e desafios nas empresas brasileiras. Revista Brasileira de Medicina Psicossomática. Rio de Janeiro, v. 1, n. 2, p. 79-83, abr/mai/jun, 1997.

GOMES, A. A. P.; QUELHAS, O. L. G. Motivação dos recursos humanos no Serviço Público, um estudo de caso sob dois ângulos teóricos. READ, ed. 35, v. 9, n. 5, set-out 2003.

LIMONGI-FRANÇA, Ana Cristina. Qualidade de Vida no Trabalho - QVT: Conceitos e práticas nas empresas da sociedade pós-industrial. 2. ed. São Paulo: Atlas, 2008.

MINAYO, M. C. S; HARTZ, Z. M. A; BUSS, P. M. Qualidade de vida e saúde, um debate necessário. Ciência \& Saúde Coletiva, n. 5, v. 1, p. 7-31, 2000.

ROBBINS, Stephen Paul. Comportamento organizacional. 9. ed. São Paulo: Prentice Hall, 2002.

RODRIGUES, Marcus Vinicius. Qualidade de vida no trabalho: evolução e análise do nível gerencial. 11. ed. Rio de Janeiro, Petrópolis: Vozes, 2008.

SILVA JUNIOR, Nelson Aleixo da. Satisfação no trabalho: um estudo entre os funcionários dos hotéis de João Pessoa. PsicoUSF, v. 6, n. 1, p. 47-57. jun. 2001.

SILVA, Daniel Nascimento, et al. Avaliação da qualidade de vida no trabalho em uma IES Paraense. Anais do XVIII ENANGRAD, Cuiabá, 1 a 3 ago. 2007.

SIQUEIRA, M. M. M., et al. Medidas do comportamento organizacional: ferramentas de diagnóstico e de gestão. Porto Alegre: Artmed, 2008.

SOUZA, E. M. A. de; PURIFICAÇÃO, M. S. da. Motivação e desempenho no trabalho: Política de Valorização do Servidor Técnico-Administrativo. Anais do $2^{\circ}$ Congresso Brasileiro de Extensão Universitária. Belo Horizonte, 12 a 15 set. 2004.

SPECTOR, Paul E. Psicologia nas organizações. São Paulo: Saraiva, 2005. 
TAMAYO, A., et al. Satisfação no trabalho. In: SIQUEIRA, M. M. M., et al. Medidas do comportamento organizacional: ferramentas de diagnóstico e de gestão. Porto Alegre: Artmed, 2008. cap. 16, p. 265-274.

TAYLOR, Frederick W. Princípios de administração científica. 7. ed. São Paulo: Atlas, 1987.

VERGARA, S. C.. Projetos e relatórios de pesquisa em administração. São Paulo: Atlas, 2000) 


\section{ANEXO A - Questionário "Satisfação no Trabalho”}

\section{PREZADO SERVIDOR}

Peço a sua colaboração e paciência para responder este questionário integrante da monografia de final do curso de Especialização em Gestão Judiciária que realizo na Universidade de Brasília (UnB).

O questionário a seguir é composto de 25 itens e versa sobre Satisfação no Trabalho. anônimo.

Suas respostas serão analisadas em conjunto e será assegurado o caráter confidencial e

$$
\text { Agradeço a sua colaboração!! }
$$

"Se desejamos saber como as pessoas sentem - qual sua experiência interior, o que lembram, como são suas emoções e seus motivos, quais as razões para agir como o fazem - por que não perguntar a elas?”

$$
\text { G.W. ALLPORT }
$$

\section{ESCALA DE SATISFAÇÃO NO TRABALHO - EST}

As frases abaixo falam a respeito de alguns aspectos do seu trabalho atual. Indique o quanto você se sente satisfeito ou insatisfeito com cada um deles. Dê suas respostas anotando, nos parênteses que antecedem cada frase, aquele número (de 1 a 7 ) que melhor representa sua resposta.

$$
\begin{aligned}
& 1=\text { Totalmente insatisfeito } \\
& 2=\text { Muito insatisfeito } \\
& 3=\text { Insatisfeito } \\
& 4=\text { Indiferente } \\
& 5=\text { Satisfeito } \\
& 6=\text { Muito satisfeito } \\
& 7=\text { Totalmente satisfeito }
\end{aligned}
$$

No meu trabalho atual sinto-me...

( ) Com o espírito de colaboração dos meus colegas de trabalho.

( ) Com o modo como meu chefe organiza o trabalho do meu setor.

( ) Com o número de vezes que já fui promovido nesta empresa.

( ) Com as garantias que a empresa oferece a quem é promovido.

( ) Com o meu salário comparado com o quanto eu trabalho.

( ) Com o tipo de amizade que meus colegas demonstram por mim.

( ) Com o grau de interesse que minhas tarefas me despertam.

( ) Com o meu salário comparado à minha capacidade profissional.

( ) Com o interesse de meu chefe pelo meu trabalho.

( ) Com a maneira como esta empresa realiza promoções de seu pessoal.

( ) Com a capacidade de meu trabalho absorver-me. 
( ) Com o meu salário comparado ao custo de vida.

( ) Com a oportunidade de fazer o tipo de trabalho que faço.

( ) Com a maneira como me relaciono com meus colegas de trabalho.

( ) Com a quantia em dinheiro que eu recebo desta empresa ao final de cada mês.

( ) Com as oportunidades de ser promovido nesta empresa.

( ) Com a quantidade de amigos que eu tenho entre meus colegas de trabalho.

( ) Com as preocupações exigidas pelo meu trabalho.

( ) Com o entendimento entre eu e meu chefe.

( ) Com o tempo que eu tenho de esperar para receber uma promoção nesta empresa.

( ) Com o meu salário comparado aos meus esforços no trabalho.

( ) Com a maneira como meu chefe me trata.

( ) Com a variedade de tarefas que realizo.

( ) Com a confiança que eu posso ter em meus colegas de trabalho.

( ) Com a capacidade profissional do meu chefe.

Finalizando esta pesquisa, preencha os dados abaixo:
$1-$ Sexo
( ) Masculino
( ) Feminino
2 - Idade
( ) de 18 a 25
( ) de 50 a 57
( ) de 26 a 33
( ) de 58 a 65
( ) de 34 a 41
( ) acima de 65 anos
( ) de 42 a 49

3-Estado Civil （）Solteiro （）Casado （）Separado-Divorciado （ ) Outros

4 - Escolaridade

( ) Ensino Fundamental (1grau)
( ) Superior Incompleto
( ) Especialização
( ) Doutorado

( ) Ensino Médio (2 grau)

( ) Superior Completo

( ) Mestrado

( ) Pós-Doutorado

5 - Cargo que ocupa
( ) Auxiliar Judiciário
( ) Técnico Judiciário
( ) Analista Judiciário
( ) Analista Administrativo

6 - Área que trabalha
( ) Administrativa
( ) Judiciária
( ) Órgãos Julgadores
( ) Gabinete

7 - Tempo de trabalho no STJ

( ) menos de 01 ano

( ) de 01 a 05

( ) de 06 a 10

( ) de 11 a $15 \quad$ ( ) de 16 a 20

( ) de 21 a 25

acima de 35 anos

$$
\text { ( ) de } 26 \text { a } 30 \quad \text { ( ) de } 31 \text { a } 35
$$

8 - Ocupa Função de Confiança ou Cargo em Comissão (FC/CJ)?

( )não ocupo

( ) sim. Assinale qual ( ) FC 2 ( ) FC 4 ( ) FC 5 ( ) FC 6

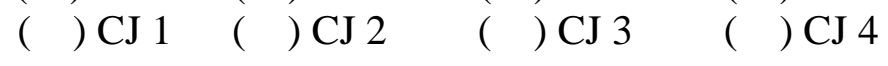

